\title{
Growth and Yield of Guar (Cyamopsis tetragonoloba L.) Genotypes under Different Planting Dates in the Semi-Arid Southern High Plains
}

\author{
Sudhir Singla1, Kulbhushan Grover ${ }^{1 *}$, Sangamesh V. Angadi1,2, Sultan H. Begna ${ }^{2}$, \\ Brian Schutte ${ }^{3}$, Dawn Van Leeuwen ${ }^{4}$ \\ ${ }^{1}$ Department of Plant and Environmental Sciences, New Mexico State University, Las Cruces, NM, USA \\ ${ }^{2}$ Agricultural Science Center, New Mexico State University, Clovis, NM, USA \\ ${ }^{3}$ Department of Entomology, Plant Pathology and Weed Science, New Mexico State University, Las Cruces, NM, \\ USA \\ ${ }^{4}$ Department of Economics, Applied Statistics and International Business, New Mexico State University, \\ Las Cruces, NM, USA \\ Email: *kgrover@nmsu.edu
}

Received 15 April 2016; accepted 17 June 2016; published 20 June 2016

Copyright (C) 2016 by authors and Scientific Research Publishing Inc.

This work is licensed under the Creative Commons Attribution International License (CC BY).

http://creativecommons.org/licenses/by/4.0/

(c) $\underset{\mathrm{EY}}{0}$ Open Access

\section{Abstract}

Guar is a drought and salt tolerant summer annual legume, which could be a potential alternative crop in the semi-arid Southern High Plains. Increased use of guar gum in oil industries has increased the demand of guar globally. Planting date effects on stand establishment, physiological parameters, and yield formation of guar genotypes were investigated at the New Mexico State University's Agricultural Science Center at Clovis, NM for two seasons (2014 and 2015). Four guar genotypes (HES 1123, Kinman, Lewis, and Matador) were tested under three planting dates (June 18, July 7, and July 22 in 2014; and June 18, July 6, and July 20 in 2015). Higher temperature and rainfall were recorded under mid-June planting than early-July and late-July plantings. Guar planted under mid-June had better stand establishment as shown by the higher number of plants $\mathbf{m}^{-2}$, better physiology as revealed by higher photosynthetic rate $\left(P_{n}\right)$, transpiration rate $\left(T_{r}\right)$, leaf area index (LAI), and SPAD values than early-July and late-July plantings. Guar planted under mid-June resulted in taller plants, and therefore, produced higher plant biomass than both of the July plantings. Yield attributing characteristics including clusters plant ${ }^{-1}$, pods plant $^{-1}$, seeds plant $^{-1}$, seed spod $^{-1}, 1000$ seed weight, and harvest index (HI) were highest under mid-June planting followed by the early-July and late-July plantings, respectively. The mid-June planting in-

${ }^{*}$ Corresponding author.

How to cite this paper: Singla, S., Grover, K., Angadi, S.V., Begna, S.H., Schutte, B. and Van Leeuwen, D. (2016) Growth and Yield of Guar (Cyamopsis tetragonoloba L.) Genotypes under Different Planting Dates in the Semi-Arid Southern High Plains. American Journal of Plant Sciences, 7, 1246-1258. http://dx.doi.org/10.4236/ajps.2016.78120 
creased seed yield by $26 \%$ and $55 \%$ over early-July and late-July (1399 vs. 1111 and $903 \mathrm{~kg} \cdot \mathrm{ha}^{-1}$ ) plantings, respectively in 2014; while the same increase in 2015 was $51 \%$ and $243 \%$ (1308 vs. 868 and $381 \mathrm{~kg} \cdot \mathrm{ha}^{-1}$ ), respectively. These results indicate that delaying planting beyond mid-June is detrimental to guar productivity. However, genotypes did not show any significant variation in their performance. Overall, warmer growing conditions and more precipitation under mid-June planting caused better growth and yield formation of guar genotypes.

\section{Keywords}

Guar, Planting Date, Genotype, Yield, Southern High Plains

\section{Introduction}

Agriculture in semi-arid regions including Southern High Plains, where water is limited and droughts are more frequent, is more challenging than humid and sub-humid regions. Approximately $30 \%$ of total irrigation withdrawal in the United States comes from the Ogallala aquifer [1], which is a 174,000 square mile body of water underlying different parts of the United States (Colorado, Kansas, Nebraska, New Mexico, Oklahoma, South Dakota, Texas and Wyoming). Levels of water in the Ogallala aquifer are declining rapidly at a rate of $6 \mathrm{~km}^{3}$ per year [2] [3]. Moreover, continuous cultivation of crops with high water consumptive use has affected the economy of regional agriculture by increasing the cost of production. Introduction of alternative crops with low water demands and low cost of production canbe one strategy to help sustain the agriculture in the region.

Guar or clusterbean (Cyamopsis tetragonoloba L.) is a drought and salinity tolerant [4]-[6] summer annual legume. Guar increases $\mathrm{N}$ and organic matter content of soil by fixing atmospheric nitrogen and adding plant residues, respectively [7] [8]. A relatively short growing season (90-120 days) [9] of guar makes it a viable rotation crop [10] with cotton, grain sorghum, small grains, vegetables, and flax [11]. An increase of 15\% in cotton yield has been noticed when grown in rotation with guar [11]. Green and succulent guar pods area good source of minerals, fibers, protein, and vitamin C [12]. Podsare consumed as a vegetable [13] by many people across the globe, particularly in South-East Asia. Guar leaves, pods, and stems are also used as forage and green manure [14] [15] in some parts of India and Pakistan.

Lately, guar is primarily cultivated as a seed crop because of its industrial use. Along with carob (Ceratonia siliqua), guar is the main source of galactomannans for industrial use [16]. Galactomannans is a polysaccharide composed of 1 - 4 mannanose backbone with varying degree of 1 - 6 galactose substitution [17]. Galactomannan extracted from guar seed is called guar gum [18]. Guar seed is made up of hull (13\% - 18\%), endosperm (34\% 43\%), and germ (41\% - 46\%) [19]. Endosperm of the guar seed which accounts for 30\% of the seed weight [20] composed mainly of galactomannans [21]. The addition of water to guar gum converts it into a thick, highly viscous gel [22]. Because of its high viscosity and water bonding properties, guar gum is used as a binding agent and stabilizer in a wide range of industries like food, chemical, pharmaceuticals, cosmetic, paint, drilling, agrochemistry, and paper industries [8] [23]-[26]. Based on the amount of polysaccharide and impurities such as protein, ash, guar gum is categorized into two broad groups: high-grade and low-grade guar gum. Food industries are major consumers of high-grade guar gum, while non-food industries primarily use the low-grade guar gum [9].

Recently, the oil industry has started using guar gum in hydraulic fracturing [21] [27]. Guar gum in the fracking fluid increases its viscosity and improves the efficiency of natural gas extraction [22]. The increased use of guar gum in oil fracking has boosted the demand of guar worldwide [27]. Gupta and Sidhartha [28] reported an increase of 139\% in the guar gum export from India to the United States between April 2012 and January 2013. The United States is the largest importer and consumer of guar gum in the world with an import of worth 1.0, 3.4, and 1.6 billion US Dollars, in 2011, 2012, and 2013 respectively [29]. Currently, the United States has around 1.7 million active natural gas wells including around 61,000 active wells in New Mexico [30]. Approximately 9 tons of guar gum is required to frack a single well which necessitates around 80 acres of guar crop cultivation to produce the needed guar gum for each well [31]. In the United States, 95-100\% of guar produced is cultivated in western Texas and southwestern Oklahoma [32]. 
The ability of guar to thrive under semi-arid conditions [21] makes it highly suitable for the Southern High Plains. Additionally, Guar adaptability has been earlier examined in New Mexico [33]. Planting date studies performed in areas with similar climate, such as NW India and Pakistan, noticed higher guar seed yield in planting period of May to August [34]. Similarly, mid-May planting of guar has been reported to produce the highest seed yield in Mediterranean environment of Italy [27]. In southwest United States, mid-April to late-May, and mid-May to early-July have been reported as optimum planting periods in South Texas and Central West Texas, respectively [11]. However, no information is available on optimum planting date for guar in the Southern High Plains. Apart from planting date, information on guar varieties that can be grown successfully in the region is also limited. Therefore, a two-year study was conducted with the objectives of determining the effects of planting dates on stand establishment, physiology, and seed yield of different guar genotypes planted in the Southern High Plains.

\section{Material and Methods}

\subsection{Experimental Site}

The field experiment was carried out during 2014 and 2015 at the New Mexico State University's Agricultural Science Center in Clovis, New Mexico (34 $06^{\prime} \mathrm{N}, 103^{\circ} 22^{\prime} \mathrm{W}$ and altitude of $1352 \mathrm{~m}$ above sea level) (Figure 1). The study location is characterized as a semi-arid climate with an average annual precipitation of $432 \mathrm{~mm}$. The total precipitation received during the study period (June-November) was $232 \mathrm{~mm}$ and $528 \mathrm{~mm}$ in 2014 and 2015 , respectively. The annual mean maximum and minimum temperatures for the region are $22^{\circ} \mathrm{C}$ and $7{ }^{\circ} \mathrm{C}$, respectively [35]. The soil type was Olton clay loam (fine, mixed, superactive, thermicaridic paleustolls) with 16.6, 24.1, and 611.5 ppm available N, P, and K, respectively in both years. The $\mathrm{pH}$ of the soil was 7.7 with $2.1 \%$ organic matter content in both years. Previous crop grown in the experimental field was wheat (Triticum aestivum L.).

\subsection{Field Preparation and Planting}

The field was cultivated and disked twice to incorporate residues from the last year's wheat crop and to prepare a smooth seedbed each year. Four genotypes (Matador, Lewis, HES 1123, and Kinman) were tested under three different planting dates (June 18, July 7, and July 22; and June 18, July 6, and July 20, respectively in 2014 and 2015). Experimental line HES 1123 was selected based on its performance in west Texas, while Matador, Lewis, and HES 1123 are already released cultivars mostly grown in part of Texas [31]. Matador plants have a strong main stem and many lateral branches while Lewis has few lateral branches. Both have a high disease tolerance. Kinman plants have glabrous leaves and stems with fine branching. Seed for all four genotypes were obtained

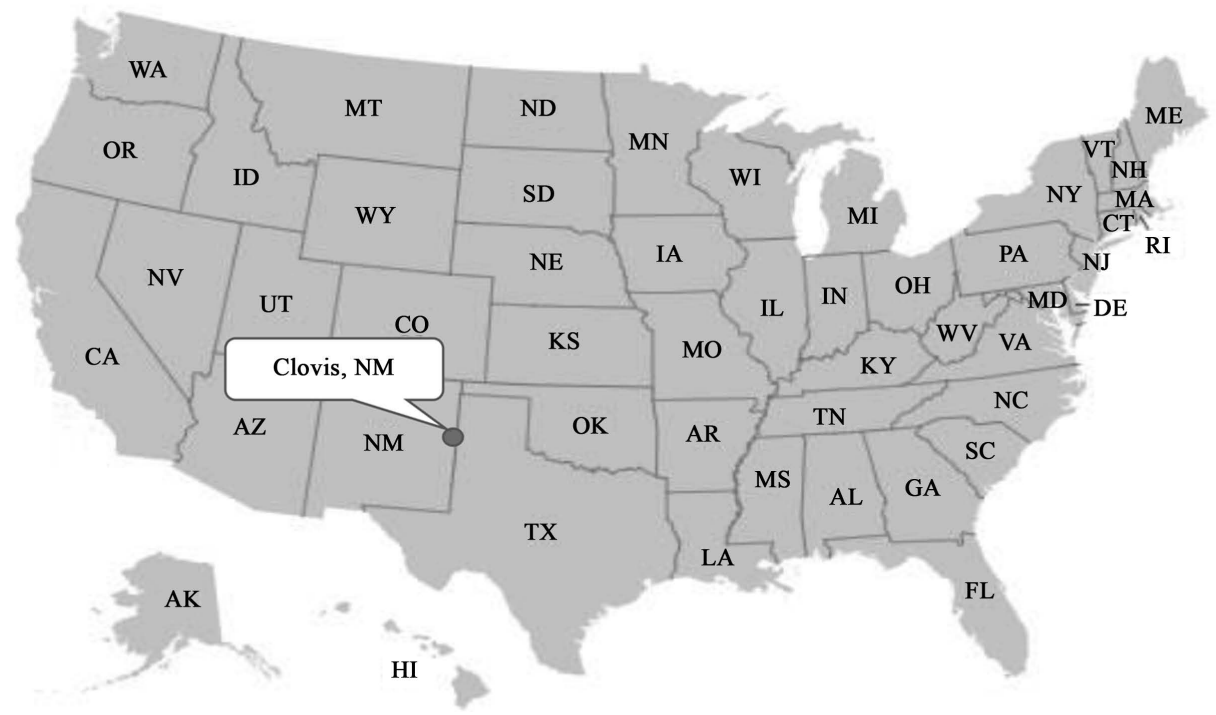

Figure 1. Geographic map of Clovis, NM. 
from Texas Tech University, Lubbock, TX. Hereafter, planting dates will be referred to as mid-June, early-July and late-July. In both years, split plot randomized block design with planting date as the whole plot factor and genotype as the sub-plot factor was implemented for this study. The whole plot size was $139 \mathrm{~m}^{2}(37.5 \mathrm{~m} \times 3.7 \mathrm{~m})$ while the sub-plot size was $34 \mathrm{~m}^{2}(9.1 \mathrm{~m} \times 3.7 \mathrm{~m})$. Planting was done on a flat surface of soil along the arch using a plot drill (Model 3P600, Great Plains Drill, Salina, KS, USA) with two passes of 11 rows for each sub-plot. Each planting was irrigated with a central pivot system. A total of $240 \mathrm{~mm}$ and $80 \mathrm{~mm}$ of irrigation was applied to the whole trial over the entire growth period in 2014 and 2015, respectively. No fertilizer was applied to guar during either of the years; however, pre-plant herbicides including Trifluralin $\left(1.2 \mathrm{~kg} \cdot a . i \cdot \mathrm{ha}^{-1}\right)$ and S-metolachlor $\left(1.1 \mathrm{~kg} \cdot\right.$ a.i. $\left.\mathrm{ha}^{-1}\right)$ were used to control weeds in 2014 and 2015, respectively. The plant population was targeted to be 272,000 plantsha ${ }^{-1}$ with a seeding rate of $9 \mathrm{~kg} \cdot \mathrm{ha}^{-1}$ in both years.

\subsection{Data Collection}

The number of plants $\mathrm{m}^{-2}$ was calculated by counting plants from two $9 \mathrm{~m}$ long rows from each sub-plot at 20 days and 40 days after planting (DAP). Photosynthetic rate $\left(\mathrm{P}_{\mathrm{n}}\right)$, transpiration rate $\left(\mathrm{T}_{\mathrm{r}}\right)$, SPAD values, and leaf area index (LAI) were measured to study the effect of planting date on guar physiology. $P_{n}$ and $T_{r}$ were measured with a portable photosynthesis system LI-COR 6400 (LI-COR, Lincoln, NE, 68504) using standard protocol. Measurements were made at a PAR (photosynthetic active radiation) value of $1500 \mu \mathrm{mol}$ photons $\mathrm{m}^{-2} \cdot \mathrm{s}^{-1}$ and a $\mathrm{CO}_{2}$ concentration of $400 \pm 10 \mu \mathrm{molmol}^{-1}$. Central leaflets of two fully expanded youngest compound leaves on the main stem were selected from each replication as suggested by Fenta et al. [36]. Same leaves were used for taking Field Scout SPAD 502 plus chlorophyll meter (Spectrum Technologies, Inc., Aurora, IL, 60504) values as an indicator of leaf chlorophyll content. SPAD values strongly correlate with leaf chlorophyll content [37]-[39]. Leaf area index (LAI) was measured using SunScan Canopy Analyzer (Delta-T Devices, Cambridge, UK).LAI measurements were made by placing a probe perpendicular to the crop rows. From each sub-plot, two samples were taken for all of the physiological parameters. All of these observations were taken on a clear sunny day between 10:00 am to 1:30 pm at the flowering stage.

Plant height from the soil surface to the tip of three representative plants was measured at maturity. Three representative plants were hand harvested from each sub-plot. Next, a total number of clusters plant ${ }^{-1}$ and pods plant $^{-1}$ were counted manually. Podscluster ${ }^{-1}$ were then calculated by dividing the clusters plant ${ }^{-1}$ by the pods plant $^{-1}$. Seeds were then removed from the pods manually and counted with the help of a digital seed counter (Seedburo Model 801 COUNT-A-PAK Seed Counter, Seedburo Equipment Co., Des Plaines, IL, 60018). Seed spod $^{-1}$ were calculated by dividing seeds plant ${ }^{-1}$ by pods plant ${ }^{-1}$. The seeds were then weighed to calculate the 1000 seed weight (g).

For measuring seed yield and harvest index, guar plants were hand harvested from an area of $1 \mathrm{~m}^{2}$ from each sub-plot. Samples were then dried to constant weight in a forced-draft oven at $60^{\circ} \mathrm{C}$ to calculate whole plant dry weight $\mathrm{m}^{-2}$. Dried guar plants were threshed using a plot combine (Model Elite Plot 2001, Wintersteiger, Ried, Austria). Seeds were cleaned with the help of a seed blower with a tube diameter of $100 \mathrm{~mm}$, type 4110.10 .00 (Seed Processing Holland BV, Enkhuizen, Netherlands, 1600 AA). Seeds were then weighed to calculate the seed weightm ${ }^{-2}$. The harvest index was calculated by dividing seed weight $\cdot \mathrm{m}^{-2}$ to whole plant dry weight $\cdot \mathrm{m}^{-2}$.

\subsection{Statistical Analysis}

Analysis of variance was conducted for yield and growth parameters using Proc Mixed Model [40] in SAS 9.4 [41]. Planting date, genotype, replication, and planting date $\times$ genotype interaction were used as fixed effects while the replication $\times$ planting date interaction was used as a random effect. A similar type of analysis was performed by Chen and Wiatrak [42]. F-tests and pair wise comparisons corresponding to significant effects (Fisher's F-protected LSD) were conducted at the 5\% significance level $(P<0.05)$. Regression analysis between photosynthetic rate and biomass accumulation, and biomass and seed yield was done using Proc Reg model in SAS 9.4 [41].

\section{Results and Discussion}

\subsection{Meteorological Parameters}

Planting dates had a significant influence on seasonal means of air and soil temperatures as well as rainfall (Table 1). Guar planted under mid-June planting experienced warmer growing conditions as indicated by higher 
Table 1. Mean air temperature $\left(\mathrm{T}_{\text {air }}\right)$, mean soil temperature $\left(\mathrm{T}_{\text {soil }}\right)$ and total rainfall $(\mathrm{RF})$ for different planting dates as measured for whole growing season at Clovis, NM in 2014 and 2015.

\begin{tabular}{|c|c|c|c|c|c|c|}
\hline & \multicolumn{2}{|c|}{$\mathrm{T}_{\mathrm{air}}$} & \multicolumn{2}{|c|}{$\mathrm{T}_{\text {soil }}$} & \multicolumn{2}{|c|}{$\mathrm{RF}$} \\
\hline & 2014 & 2015 & 2014 & 2015 & 2014 & 2015 \\
\hline Planting Date & \multicolumn{4}{|c|}{$\left({ }^{\circ} \mathrm{C}\right)$} & \multicolumn{2}{|c|}{$(\mathrm{mm})$} \\
\hline Mid-June & 23.1 & 22.2 & 25.3 & 24.0 & 153.7 & 442.0 \\
\hline Early-July & 21.2 & 21.5 & 23.4 & 23.0 & 123.4 & 427.5 \\
\hline Late-July & 17.8 & 18.9 & 20.5 & 20.3 & 118.4 & 415.5 \\
\hline
\end{tabular}

mean soil and air temperatures compared to both July plantings in both years (Table 1). The late-July planting had least mean soil and air temperatures when averaged across the growing season (Table 1). Highest rainfall was received by guar planted under mid-June followed by early-July and late-July plantings in both years. The year 2015 growing season received higher rainfall compared to the year 2014 (Table 1). Guar planted under mid-June also encountered warmer growing conditions for the initial growth period (from planting to 20 and 40 DAP) (Table 2).

\subsection{Stand Establishment}

The mid-June planting recorded highest plants $\mathrm{m}^{-2}$ among planting dates in both years (Table 3). Plant count done at both times indicated better stand establishment under mid-June planting than the July plantings. Plant count done at 40 DAP had the higher number of plants $\mathrm{m}^{-2}$ than at 20 DAP (Table 3) among all planting dates and genotypes in both years. Temperature plays an important role in facilitating the germination of seed legumes [43]. Soil temperature greater than $30^{\circ} \mathrm{C}$ accelerates guar seed germination [9]. Higher temperature (Table 2) might have resulted in more germination, thus higher seedling emergence under the mid-June planting (Table 3). Genotypic variation was also noticed for seedling emergence in both years. The higher number of plantsm ${ }^{-2}$ in Lewis genotype in both years represents better stand establishment while Matador in 2015 and Kinman in 2016 resulted in the least seedling emergence. The interaction between treatments was found non-significant at $P>$ 0.05 in both years.

\subsection{Physiological Parameters}

Physiological parameters of guar were significantly affected by planting date. A higher photosynthetic rate $\left(\mathrm{P}_{\mathrm{n}}\right)$ under mid-June planting of guar showed better carbon accumulation compared to the two other July plantings. However, transpiration rate $\left(T_{r}\right)$ did not show any significant variation between mid-June and early-July plantings in both years. Guar planted in late-July had the lowest $P_{n}$ and $T_{r}$ (Table 4). Guar planted under mid-June planting resulted in $56 \%$ and $104 \%$, and $70 \%$ and $183 \%$ higher $\mathrm{P}_{\mathrm{n}}$ than early-July and late-July plantings, respectively in 2014 and 2015 (Table 4). Genotypic differences were non-significant for both $P_{n}$ and $T_{r}$ in both years; however, Matador had a higher $\mathrm{P}_{\mathrm{n}}$ than Kinman in 2014.

Favorable weather conditions (higher temperature and more rainfall) (Table 1 and Table 2) might have triggered $P_{n}$ and $T_{r}$ of guar genotypes under mid-June planting in both years. Increased air temperature resulted in higher $\mathrm{P}_{\mathrm{n}}$ of perennial herbs (Acaena cylindrostachya and Senecio formosus) [44]. Apart from temperature, higher rainfall is also believed to have a positive impact on $\mathrm{P}_{\mathrm{n}}$ of pigeon pea [45]. Leaf chlorophyll content and leaf area are other important parameters in determining the photosynthesis efficiency [46]. SPAD values were significantly affected by planting date; however, genotypic differences were not significant in both years. Guar planted under mid-June had a higher leaf chlorophyll content as indicated by higher SPAD values than the late-July planting, and both July plantings, respectively in 2014 and 2015 (Table 4). Warmer weather (Table 1) might have led to increased chlorophyll content of guar planted under the mid-June in both years. Higher chlorophyll content at warmer temperatures was also noticed in maize leaves by Haldimann [47]. Planting dates and genotypes affected leaf area index (LAI) consistently in both years. The mid-June planting produced the highest LAI, which increased by $33 \%$ and $88 \%$, and $4 \%$ and $47 \%$ over the early-July and late-July plantings, respectively in 2014 and 2015. Vickery et al. [48] found a positive linear relationship between $\mathrm{P}_{\mathrm{n}}$ and LAI in Dactylis 
Table 2. Mean soil temperature over first 20 days after planting $\left(\mathrm{T}_{20}\right)$ and 40 days after planting $\left(\mathrm{T}_{40}\right)$ for different planting dates as measured at NMSU campus, Las Cruces, NM in 2014 and 2015.

\begin{tabular}{cccccc}
\hline & \multicolumn{3}{c}{$\mathrm{T}_{20}$} & & $\mathrm{~T}_{40}$ \\
\cline { 2 - 5 } & 2014 & 2015 & 2014 & 2015 \\
\hline Planting Date & & & & \\
Mid-June & 27.2 & 26.6 & 27.0 & 25.9 \\
Early-July & 26.7 & 25.9 & 26.4 & 25.6 \\
Late-July & 26.6 & 25.6 & 25.4 & 25.3 \\
\hline
\end{tabular}

Table 3. Effect of three planting dates on stand establishment of four guar genotypes on 20 days and 40 days after planting (DAP) at Clovis, NM in 2014 and 2015.

\begin{tabular}{|c|c|c|c|c|}
\hline & \multicolumn{2}{|c|}{2014} & \multicolumn{2}{|c|}{2015} \\
\hline & 20 DAP & $40 \mathrm{DAP}$ & 20 DAP & $40 \mathrm{DAP}$ \\
\hline Planting date (P) & \multicolumn{4}{|c|}{$\left(\right.$ plantsm $\left.^{-2}\right)$} \\
\hline Mid-June & $23.4 \mathrm{a}^{\mathrm{z}}$ & $28.2 \mathrm{a}$ & $22.6 \mathrm{a}$ & $25.6 \mathrm{a}$ \\
\hline Early-July & $19.6 \mathrm{~b}$ & $21.7 \mathrm{~b}$ & $17.5 \mathrm{~b}$ & $19.5 b$ \\
\hline Late-July & $15.4 \mathrm{c}$ & $16.3 \mathrm{c}$ & $13.7 \mathrm{~b}$ & $16.7 \mathrm{~b}$ \\
\hline \multicolumn{5}{|l|}{ Genotype (G) } \\
\hline HES 1123 & $17.9 \mathrm{bc}$ & $20.5 b c$ & $18.7 \mathrm{ab}$ & 21.3ab \\
\hline Kinman & $19.5 b$ & $22.1 b$ & $15.0 \mathrm{c}$ & $17.6 \mathrm{c}$ \\
\hline Lewis & 24.3a & $26.9 a$ & $21.2 \mathrm{a}$ & 23.9a \\
\hline Matador & $16.2 \mathrm{c}$ & $18.8 \mathrm{c}$ & $16.8 \mathrm{bc}$ & $19.4 \mathrm{bc}$ \\
\hline Interaction $(\mathrm{P} \times \mathrm{G})$ & NS & NS & NS & NS \\
\hline
\end{tabular}

${ }^{\mathrm{z}}$ Means within a column and particular effect followed by the same letter(s) are not significantly different $(P>0.05)$. NS - Non significant at $P>0.05$.

Table 4. Effect of three planting dates on photosynthetic rate $\left(\mathrm{P}_{\mathrm{n}}\right)$, transpiration rate $\left(\mathrm{T}_{\mathrm{r}}\right)$, leaf area index (LAI), and SPAD value of four guar genotypes at 50\% flowering stage at Clovis, NM in 2014 and 2015.

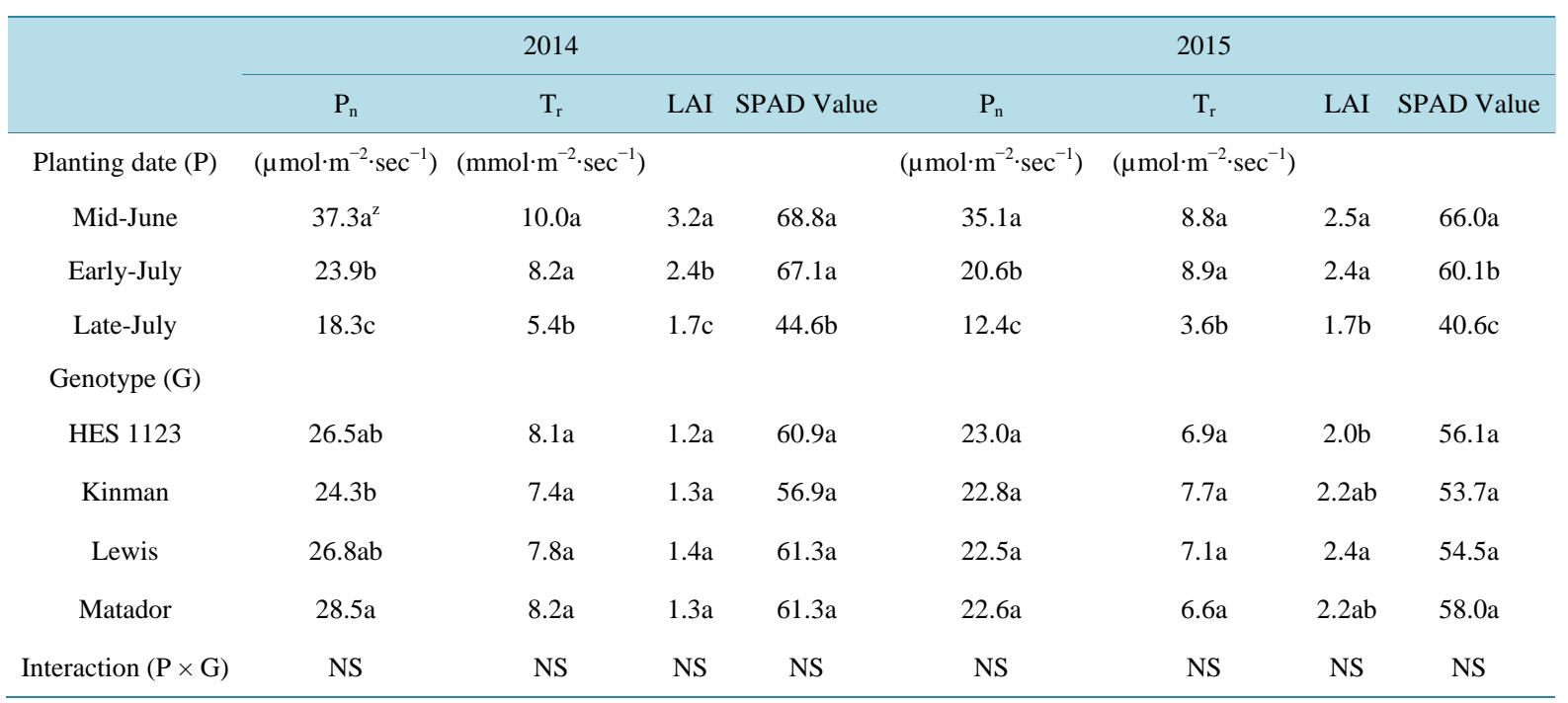

${ }^{\mathrm{z}}$ Means within a column and particular effect followed by the same letter(s) are not significantly different $(P>0.05)$. NS-Non significant at $P>0.05$. 
glomerata plants. The late-July planting produced the least LAI (Table 4). Planting date produced significant variation in LAI of guar grown in the tropical climate of India [49]. A Study carried out in Haryana, India by Taneja et al. [50] also showed higher LAI under mid-June planting than July planting of guar. Genotypic differences were non-significant in 2014; however, the opposite was true in 2015. Lewis showed a higher LAI than HES 1123 in 2015. The interaction between planting dates and genotypes were non-significant for all physiological parameters at $P>0.05$ in both years. Choudhary et al. [51] reported significant variation in LAI of various guar genotypes.

\subsection{Growth and Biomass Production}

Plant height was significantly affected by planting dates and genotypes in both years (Table 5). The mid-June planting resulted in taller plants than late-July planting. Plant height in early-July planting was not significantly

Table 5. Effect of different planting dates on plant height, biomass, yield and yield attributing characters of various guar genotypes at maturity at Las Cruces, NM in 2014 and 2015.

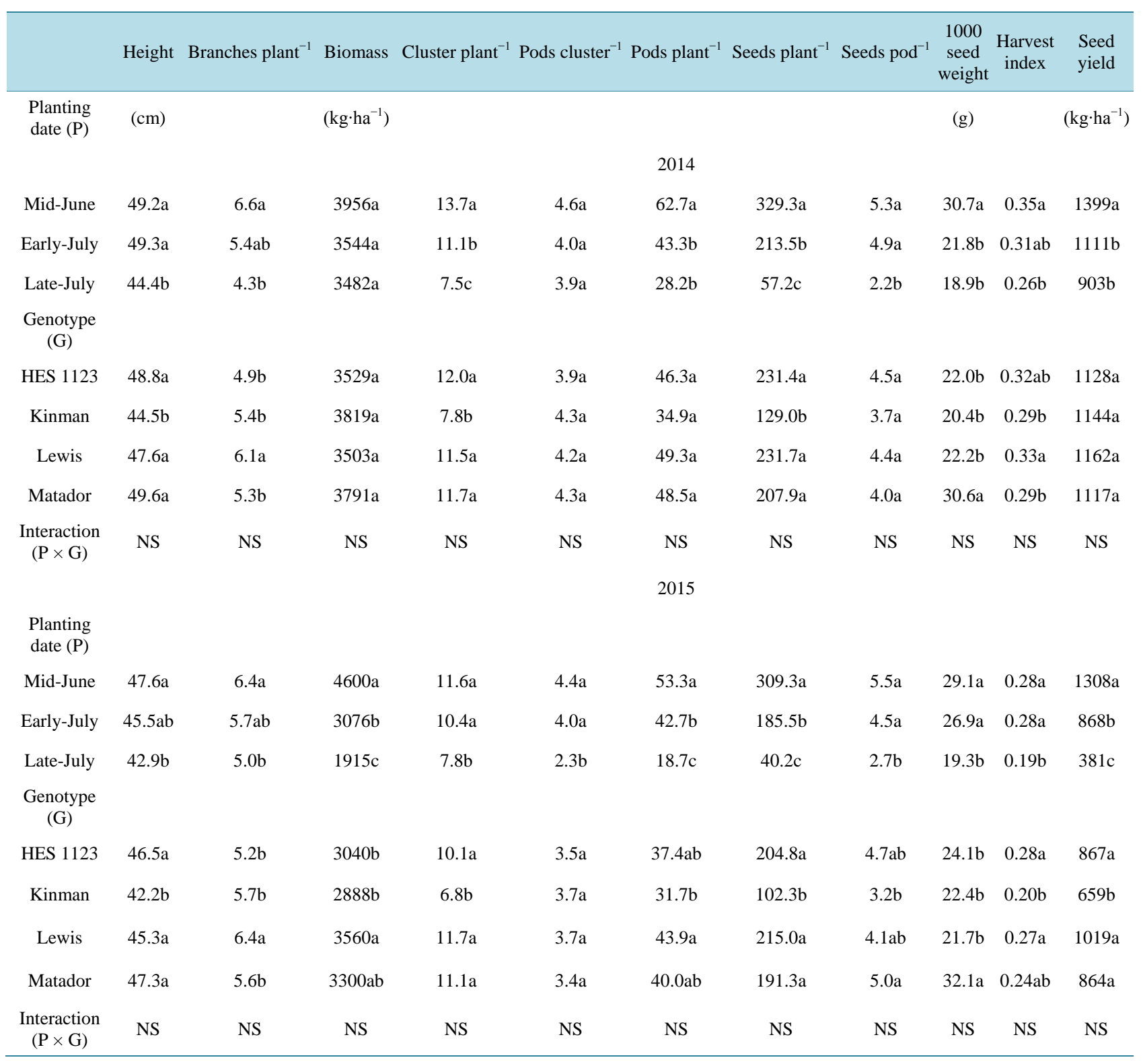

${ }^{\mathrm{z}}$ Means within a column and particular effect followed by the same letter(s) are not significantly different $(P>0.05)$. NS-Non significant at $P>0.05$. 
different from early or late plantings, with the exception of late planting in 2014. Among genotypes, Kinman was the shortest plant in both years (Table 5). The interaction between planting dates and genotypes for plant height was non-significant at $P>0.05$. Mean plant height over planting dates and genotypes ranged from 44.4 $\mathrm{cm}$ to $49.6 \mathrm{~cm}$, and $42.2 \mathrm{~cm}$ to $47.6 \mathrm{~cm}$, respectively in 2014 and 2015. A study conducted by Kalyani [8] in Tirupati, India also showed a significant effect of planting date on guar plant height under rainfed conditions. May planting of guar resulted in taller plants compared to June planting in the Mediterranean environment of Italy [27]. In contrast, Ali et al. [52] found taller plants under June planting compared to May and July plantings in dry land regions of Pakistan.

Significantly, more branches plant ${ }^{-1}$ were produced by the mid-June planting of guar than late-July planting (Table 5); however, the differences were not significant from early-July planting in both years. In a research conducted on agricultural research land in Haryana, India variation in the number of branches plant ${ }^{-1}$ of guar with changing planting dates was also observed by Taneja et al. [50]. Among genotypes, Lewis produced the highest number of branches plant ${ }^{-1}$. The interaction between treatments was non-significant for branches plant ${ }^{-1}$ at the $5 \%$ level of significance.

Treatments did not produce any significant effect on final plant biomass in 2014; however, noticeable variability was observed in 2015. The mid-June planted guar had the highest plant biomass in 2015 (Table 5). Shorter guar plants in the late-July planting produced the least plant biomass. The mid-June planting increased plant biomass by $50 \%$ and $140 \%$ than the early-July and late-July plantings in 2015. Increased photosynthesis under mid-June planting might have caused higher biomass accumulation as indicated by the relationship found between photosynthetic rate and plant biomass accumulation (Figure $2, \mathrm{R}^{2}=0.40$ ).In a study conducted by Reich et al. [53] on 9 different tree species, an increase in biomass accumulation rate with increasing photosynthetic rate was reported. Kalyani [8] observed significant variation in final plant biomass of guar, ranging from 3490 $\mathrm{kg} \cdot \mathrm{ha}^{-1}$ to $6831 \mathrm{~kg} \cdot \mathrm{ha}^{-1}$, over different planting dates. Also, June planted guar seemed to have the highest biomass compared to May and July plantings in rainfed regions of Pakistan [52]. Genotypic variation for plant

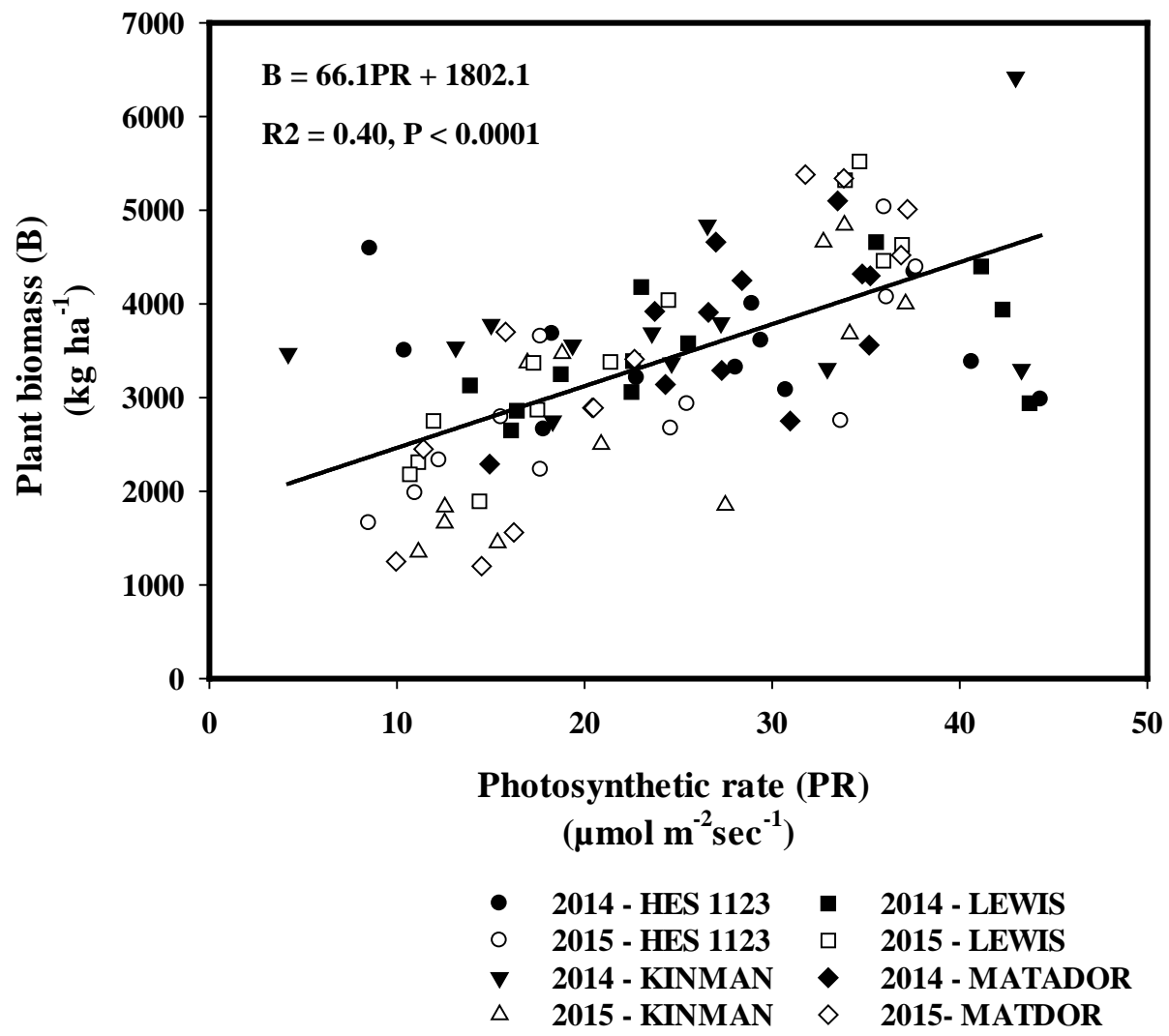

Figure 2. Guar final plant biomass as a function of photosynthetic rate $\left(P_{n}\right)$ measured during 2014 and 2015 at Clovis, NM. 
biomass was non-significant in 2014; however, significant variation was seen in 2015. Lewis produced more plant biomass than HES 1123 and Kinman in 2015. The interaction between treatments was non-significant for plant biomass at $P>0.05$. Favorable weather conditions during mid-June planting growing season helped guar to have taller and more branched plants and thus resulted in higher biomass accumulation.

\subsection{Yield and Yield Characters}

A significant effect of planting date on guar seed yield was observed in both years; however, genotypic differences were significant only in 2015 (Table 5). The mid-June planting had significantly higher seed yield than both of the July plantings in both years. An increase of $26 \%$ and $55 \%$, and $51 \%$ and $243 \%$ was found in seed yield of the mid-June planting of guar over the early-July and late-July plantings, respectively in 2014 and 2015. The early-June planting of guar resulted in $118 \%$ higher seed yield than early-July planting in Knox county of Texas, USA [54]. In that study, less transformation of buds to full pods in early-July planting, indicated by high bud to pod ratio (5:1), resulted in reduced seed yield of early-July planting compared to the early-June planting, which had a low bud to pod ratio (3:1). Under rainfed conditions, Ali et al. [52] showed that early-June planting of guar produced significantly higher seed yield compared to May, late-June, and early-July plantings. A study conducted by Yadav et al. [55] indicated highest guar seed yield when planted in late-June. In their study, late-June planting increased guar seed yield by $21 \%$ and $35 \%$ over mid-July planting, respectively in 2000 and 2001. In contrast, Taneja et al. [50] found an increase of $26 \%$ and $72 \%$ in the seed yield of guar under July 10 planting over June 20 and July 30 plantings, respectively. Reduced seed yield in the July 30 planting date was attributed to low accumulated heat and curtailed the growth period. Gresta et al. [27] indicated a 9\% in increase in seed yield of guar planted in early-May compared to late-June planting in the Mediterranean environment of Italy. Increased plant biomass might have increased the seed yield of mid-June planted guar as suggested by the significant relationship found between plant biomass and guar seed yield (Figure $3, \mathrm{R}^{2}=0.78$ ). Genotypes showed significant variation for seed yield in 2015 only. Lewis, HES 1123, and Matador had higher seed yield

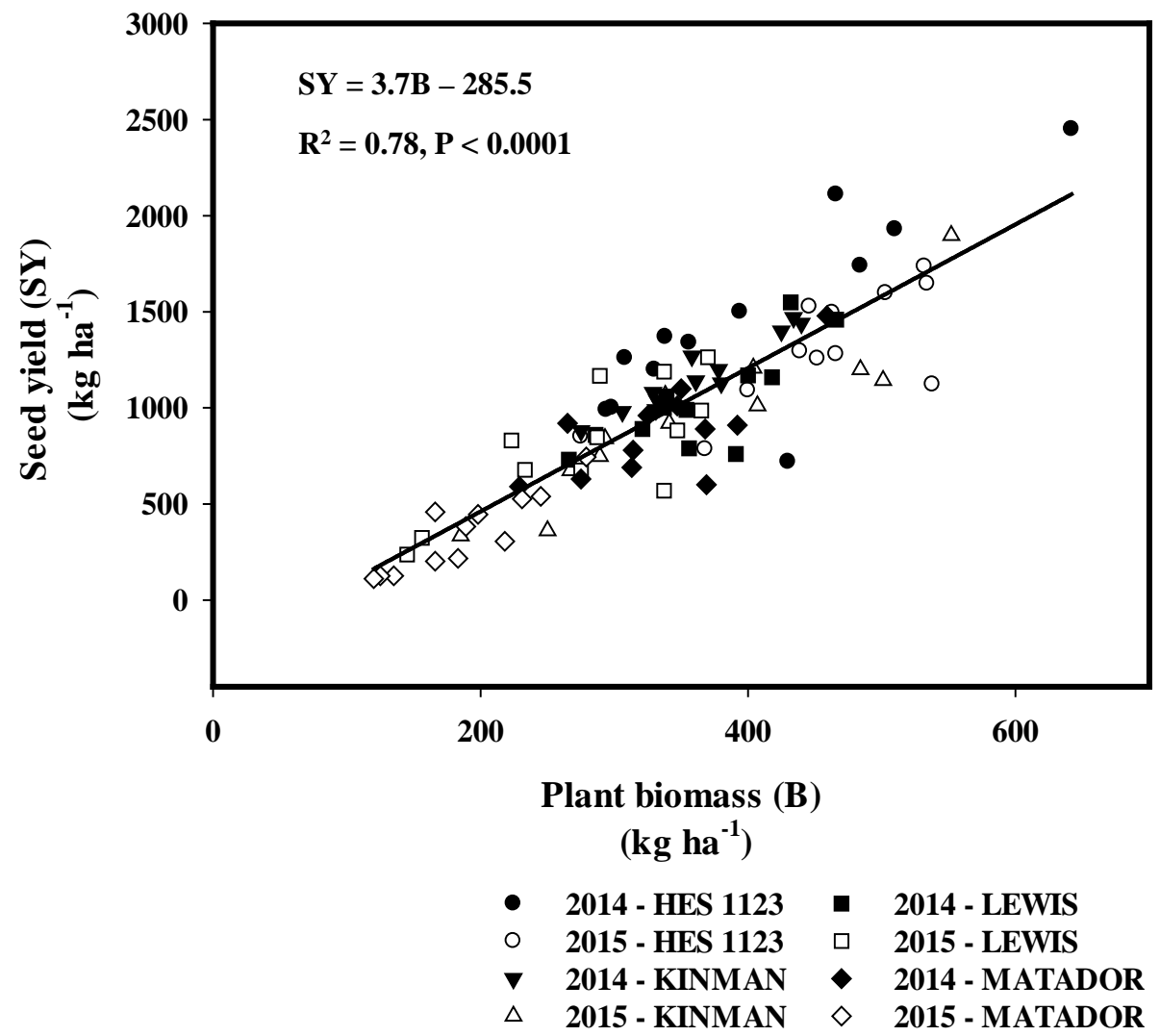

Figure 3. Guar final seed yield as a function of plant biomass measured during 2014 and 2015 at Clovis, NM. 
than Kinman in 2015. Gresta et al. [27]; Kalyani [8]; Punia et al. [56] also observed significant variation among various genotypes for seed yield. Mean seed yield across planting dates and genotypes ranged from 903 to 1399 $\mathrm{kg} \cdot \mathrm{ha}^{-1}$ and 381 to $1308 \mathrm{~kg} \cdot \mathrm{ha}^{-1}$, respectively in 2014 and 2015. The non-significant interaction between planting dates and genotypes was found for seed yield at $P>0.05$ in both years.

Treatments affected yield characters [clusters plant ${ }^{-1}$, pods plant ${ }^{-1}$, seeds plant ${ }^{-1}$, seed spod ${ }^{-1}, 1000$ seed $^{-1}$

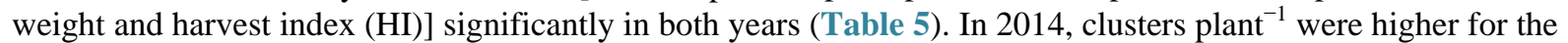
mid-June planting, followed by early and late-July plantings (Table 5). However, in 2015, clusters plant ${ }^{-1}$ were $^{-}$ similar under mid-June and early-July plantings. In both years, the mid-June planting produced a higher number of pods plant ${ }^{-1}$ than early and late-July plantings (Table 5). The mid-June planting had 23\% and 83\%, and 12\% and $49 \%$ higher clusters plant ${ }^{-1}$ than the early-July and late-July plantings, respectively in 2014 and 2015. Similarly, the mid-June planting had $45 \%$ and $122 \%$, and $25 \%$ and $185 \%$ higher pods plant $^{-1}$ than the early-July and late-July plantings, respectively in 2014 and 2015. Planting date showed significant variation for the number of clusters plant ${ }^{-1}$ and pods plant ${ }^{-1}$ for guar [8] [50] [57]-[59]. Genotype variation for clusters plant ${ }^{-1}$ and pods $^{-[3}$ plant $^{-1}$ was non-significant in 2014. However, variation was significant in 2015. Kinman had a lower number of

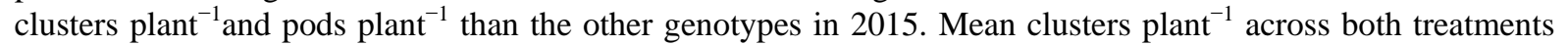

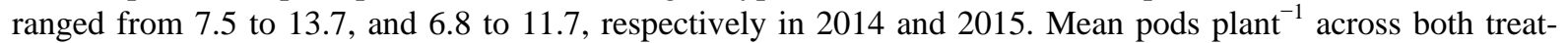
ments ranged from 28.2 to 62.7 , and 18.7 to 53.3, respectively in 2014 and 2015. In 2014, podscluster ${ }^{-1}$ did not $^{-}$ show any significant variation among planting dates and genotypes. However, in 2015, mid-June and early-July plantings had a higher number of podscluster ${ }^{-1}$ than late-July planting. In contrast, significant variation in the number of podscluster ${ }^{-1}$ of guar over different planting dates was found by Kalyani [8] and Patil [60].

In both years, the mid-June planting produced the maximum number of seeds plant ${ }^{-1}$, followed by early and late-July plantings (Table 5). The mid-June and early-July plantings had a higher number of seed spod ${ }^{-1}$ than late-July planting. A higher number of seed $\operatorname{spod}^{-1}$ and pods plant ${ }^{-1}$ in the mid-June planting caused an increased number of seeds plant ${ }^{-1}$. The mid-June planting produced 54\% and 475\%, and 67\% and 670\% higher number of seeds plant ${ }^{-1}$ than early-July and late-July plantings, respectively in 2014 and 2015. The mid-June planting produced $8 \%$ and $140 \%$, and $22 \%$ and $104 \%$ higher number of seeds pod ${ }^{-1}$ than early-July and late-July plantings, respectively in 2014 and 2015.

A study conducted by Gresta et al. [27]; Kalyani [8]; Taneja et al. [50]; Tiwana and Tiwana [42] also showed significant variation in seed spod ${ }^{-1}$ of guar under different planting dates. Genotypic variation for seeds plant ${ }^{-1}$ and seed spod ${ }^{-1}$ was observed. Kinman produced the least number of seeds plant ${ }^{-1}$ and seed spod ${ }^{-1}$ in both years. Lewis produced the maximum number of seeds plant ${ }^{-1}$ in both years; however, the difference was significant than Kinman only. Seed spod ${ }^{-1}$ did not vary significantly among genotypes in 2014; however, the difference was significant in 2015. Kinman produced a significantly fewer number of seed spod ${ }^{-1}$ than Matador in 2015.

In 2014, guar planted in the mid-June resulted in higher 1000 seed weight than July plantings. However, in 2015, 1000 seed weight was similar under mid-June and early-July plantings. 1000 seed weight of guar differs with changing planting dates [8] [27] [50] [57] [59]. The early planting of guar resulted in a higher 1000 seed weight than late planting [8] [27] [57]. Among genotypes, Matador had the highest 1000 seed weight in both years, which differed significantly from the rest of the genotypes. In 2014, the mid-June planting resulted in higher HI than late-July planting; however, in 2015, both mid-June and early-July plantings had higher HI than late-July planting. The mid-June planting increased HI by $13 \%$ and 35\% over early-July and late-July plantings in 2014. Among genotypes, Lewis and HES 1123 had the highest HI in 2014 and 2015, respectively. Lewis differed significantly from Matador and Kinman in 2014, and HES differed significantly from Kinmanin 2015. Treatments did not produce any significant interaction for yield and yield characters at $P>0.05$ in both years.

\section{Conclusion}

Planting date showed a significant effect on yield formation of guar genotypes in the Southern High Plains. The present study indicated that planting of any of the tested guar genotypes around mid-June was the best for higher seed yield. More studies with earlier planting dates (in April and May) and more diverse genotypes could reveal more information about the best planting period in the Southern High Plains. Favorable weather conditions prevailed during the growing season of the mid-June planting helped guar to achieve higher seed yield than other planting dates. Warmer weather conditions for the mid-June planted guar led to higher plant establishment, higher photosynthetic rate, higher biomass accumulation, and consequently, higher seed yield of guar under 
mid-June planting than under early-July and late-July plantings. Interestingly, no genotype significantly outperformed the other; however, Lewis had the highest seed yield. Weather differences between the two years altered guar performance which resulted in higher seed yield in the year 2014 than 2015.

\section{Acknowledgements}

Financial support from Agricultural Science Center, Clovis, NM is acknowledged. Technical support from Aaron Scott and David Rodriguez is also much appreciated.

\section{References}

[1] Maupin, M.A. and Barber, N.L. (2005) Estimated Withdrawals from Principal Aquifers in the Unites States. US Geological Survey Circular, 1279, 46. http://pubs.usgs.gov/circ/2005/1279/

[2] Scanlon, B.R., Faunt, C.C., Longuevergne, L., Reedy, R.C., Alley, W.M., McGuirre, V.L. and McMahon, P.B. (2012) Groundwater Depletion and Sustainability of Irrigation in the US High Plains and Central Valley. Proceedings of the National Academy of Sciences of the United States of America, 109, 9320-9325. http://dx.doi.org/10.1073/pnas.1200311109

[3] Rosenberg, N.J., Epstein, D.J, Wang, D., Vail, L., Srinivasam, R. and Arnold, J.G. (1999) Possible Impacts of Global Warming on the Hydrology of the Ogallala Aquifer Region. Climate Change, 42, 677-692. http://dx.doi.org/10.1023/A:1005424003553

[4] Ashraf, M.Y., Akhtar, K., Sarwar, G. and Ashraf, M. (2005) Role of the Rooting System in Salt Tolerance Potential of Different Guar Accessions. Agronomy for Sustainable Development, 25, 243-249. http://dx.doi.org/10.1051/agro:2005019

[5] Francois, L.E., Donovan, T.J. and Maas, E.V. (1990) Salinity Effects on Emergence, Vegetative Growth and Seed Yield of Guar. Agronomy Journal, 82, 587-592. http://dx.doi.org/10.2134/agronj1990.00021962008200030030x

[6] Gresta, F., Luca, A.D., Strano, A., Falcone, G., Santonoceto, C., Anastasi, U. and Gulisano, G. (2014) Economic and Environmental Sustainability Analysis of Guar (Cyamopsis tetragonoloba L.) Farming Process in a Mediterranean Area: Two Case Studies. Italian Journal of Agronomy, 9, 20-24. http://dx.doi.org/10.4081/ija.2014.565

[7] Elsheikh, E.A.E. and Ibrahim, K.A. (1999) The Effect of Bradyrhizobium Inoculation on Yield and Seed Quality of Guar (Cyamopsis tetragonoloba L.). Food Chemistry, 65, 183-187. http://dx.doi.org/10.1016/S0308-8146(98)00192-7

[8] Kalyani, D.L. (2012) Performance of Cluster Bean Genotypes under Varied Time of Sowing. Legume Research, 35, 154-158.

[9] Undersander, D.J., Putnam, D.H., Kaminski, A.R., Kelling, K.A., Doll, J.D., Oplinger, E.S. and Gunsolus, J.L. (1991) Guar. Alternative Field Crops Manual. Uni. of Wisconsin-Extension. https://www.hort.purdue.edu/newcrop/afcm/guar.html

[10] Tucker, B. and Foraker, R. (1975) Cotton and Grain Sorghum Yields Following Guar and Cowpeas Compared to Continuous Cropping. Oklahoma Agricultural Experimental Station Research, 728.

[11] Tripp, L.D., Lovelace, D.A. and Boring, E.P. (2011) Keys to Profitable Guar Production. Texas Agricultural Experimental Station Bulletin, 7-11. http://lubbock.tamu.edu/files/2011/10/keysguarprod1977 1.pdf

[12] Aykroyd, U.R. (1963) Indian Council of Medical Research, Special Report. Vegetable, National Book Trust India, New Delhi, 42, 188-191.

[13] Whistler, R.L. and Hymowitz, T. (1979) Guar: Agronomy, Production, Industrial Use, and Nutrition. Purdue University Press, West Lafayette.

[14] Chudzikowski, R.J. (1971) Guar Gum and its Applications. Journal of the Society of Cosmetics Chemists, 22, 43-60.

[15] Siddaraju, R., Narayanaswamy, S., Ramegowda and Prasad, S.R. (2010) Studies on Growth, Seed Yield and Yield Attributes as Influenced by Varieties and Row Spacing in Cluster Bean (Cyamopsis tetragonoloba L.). Mysore Journal of Agricultural Sciences, 44, 16-21.

[16] Jackson, K.J. and Doughton, J.A. (1982) Guar: A Potential Industrial Crop for Dry Tropics of Australia. Journal of the Australian Institute of Agricultural Science, 42, 17-31.

[17] Marten, J.J. and Brunstedt, J. (2001) In Vivo Modification of the Cell Wall Polysaccharide Galactomannan of Guar Transformed with a Glycosidase Gene from Senna. Molecular Breeding, 7, 211-219. http://dx.doi.org/10.1023/A:1011375605835

[18] Miyazawa, T. and Funazukuri, T. (2006) Noncatalytic Hydrolysis of Guar Gum under Hydrothermal Conditions. Carbohydrate Research, 341, 870-877. http://dx.doi.org/10.1016/j.carres.2006.02.014

[19] Srivastava, S., Anees, K. and Ramani, R. (2011) Promise of Guar Meal. Scientific Reporter, 38-39. 
[20] Sabahelkheir, M.K., Abdalla, A.H. and Nouri, S.H. (2012) Quality Assessment of Guar Gum (Endosperm) of Guar (Cyamopsis tetragonoloba). ISCA Journal of Biological Sciences, 1, 67-70.

[21] Abidi, N., Liyanage, S., Auld, D., Imel, R.K., Norman, L., Grover, K., Angadi, S., Singla, S. and Trostle, C. (2015) Challenges and Opportunities for Increasing Guar Production in the United States to Support Unconventional Oil and Gas Production. In: Uddameri, V., et al., Eds., Hydraulic Fracturing Impacts and Technologies, CRC Press, Boca Raton, 207-226. http://dx.doi.org/10.1201/b18581-13

[22] King, H. (2008) Guar Beans and Hydraulic Fracturing. http://geology.com/stories/13/guar-beans-and-hydraulic-fracturing/

[23] Lubbe, A. and Verpoorte, R. (2011) Cultivation of Medicinal and Aromatic Plants for Specialty Industrial Materials. Industrial Crops and Products, 34, 785-801. http://dx.doi.org/10.1016/j.indcrop.2011.01.019

[24] Mudgil, D., Barak, S. and Khatkar, B.S. (2011) Guar Gum: Processing, Properties and Food Applications-A Review. Journal of Food Science and Technology, 51, 409-418. http://dx.doi.org/10.1007/s13197-011-0522-x

[25] Sainy, M.I. and Paroda, R.S. (1984) Guar Cultivation in Haryana, India. Department of Plant Breeding, Chaudhary Charan Singh Agricultural Journal, 104, 199-203.

[26] Vaughna, S.F., Berhowa, M.A., Winkler-Mosera, J.K. and Leeb, E. (2011) Formulation of a Biodegradable, Odor-Reducing Cat Litter from Solvent-Extracted Corn Dried Distillers Grains. Industrial Crops and Products, 34, 999-1002. http://dx.doi.org/10.1016/j.indcrop.2011.03.005

[27] Gresta, F., Sortino, O., Santonoceto, C., Issi, L., Formantici, C. and Galante, Y. (2013) Effects of Sowing Times on Seed Yield, Protein and Galactomannans Content of Four Varieties of Guar (Cyamopsis tetragonoloba L.) in a Mediterranean Environment. Industrial Crops and Products, 41, 46-52. http://dx.doi.org/10.1016/j.indcrop.2012.04.007

[28] Gupta, S. and Sidhartha. (2013) Humble Guar Gum is India’s Top Farm Export. Times of India, 10 March 2013. http://timesofindia.indiatimes.com/business/india-business/Humble-guar-gum-is-Indias-top-farm-export/articleshow/18 885452.cms

[29] Singh, S.K. (2014) An Analysis of Performance of Guar Crop in India. Report Prepared for USDA-FAS. http://gain.fas.usda.gov/Recent\%20GAIN\%20Publications/An\%20Analysis\%20of\%20Guar\%20Crop\%20in\%20India_ New\%20Delhi_India_5-6-2014.pdf

[30] Kelso, M. (2015) 1.7 Millions Wells in the US-A 2015 Update. FracTracker Alliance. http://www.fractracker.org/2015/08/1-7-million-wells/

[31] Trostle, C. (2013) Guar in West Texas. Texas A\&M AgriLife Extension. http://lubbock.tamu.edu/files/2013/06/Guar-Production-Industry-Texas-May2013-Trostle.pdf

[32] Trostle, C.D. (2012) Guar in United States_-Prospects for Domestic Seed Supply and Impact on Gum Supplies. Texas AgriLife Research \& Extension Center, Lubbock.

[33] Grover, K. (2012) Guar: A Potential Specialty Crop in New Mexico. Cooperative Extension Service, New Mexico State University, Las Cruces. http://aces.nmsu.edu/ces/plant_sciences/2012-news-you-can-use.html

[34] Losavio, N., Ventrella, D. and Vonella, A.V. (2002) Environmental Adaptability and Productive Potential of the Guar Grown in Irrigation System in Southern Italy. Agronomy Journal, 36, 171-175.

[35] Contreras-Govea, F., Marsalis, M., Angadi, S., Smith, G., Lauriault, L. and Van Leeuwen, D. (2011) Fermentability and Nutritive Value of Corn and Forage Sorghum Silage When in Mixture with Lablab Bean. Crop Science, 51, 13071313. http://dx.doi.org/10.2135/cropsci2010.05.0282

[36] Fenta, B.A., Driscoll, S.P., Kunert, K.J. and Foyer, C.H. (2012) Characterization of Drought Tolerance Traits in Nodulated Soya Beans: The Importance of Maintaining Photosynthesis and Shoot Biomass under Drought Induced Limitations on Nitrogen Metabolism. Journal of Agronomy and Crop Science, 198, 92-103. http://dx.doi.org/10.1111/j.1439-037X.2011.00491.X

[37] Uddiling, J., Gelang-Alfredsson, J., Piikki, K. and Pleijel, H. (2007) Evaluating the Relationship between Leaf Chlorophyll Concentration and SPAD-502 Chlorophyll Meter Readings. Photosynthesis Research, 91, 37-46. http://dx.doi.org/10.1007/s11120-006-9077-5

[38] Hoel, B.O. and Solhaug, K.A. (1998) Effect of Irradiance on Chlorophyll Estimation with the Minolta SPAD-502 Leaf Chlorophyll Meter. Annals of Botany, 82, 389-392. http://dx.doi.org/10.1006/anbo.1998.0683

[39] Markwell, J., Osterman, J.C. and Mitchell, J.L. (1995) Calibration of the Minolta SPAD-502 Leaf Chlorophyll Meter. Photosynthesis Research, 46, 467-472. http://dx.doi.org/10.1007/BF00032301

[40] Littell, R.C., Milliken, G.A., Stroup, W.W. and Wolfinger, W.W. (1996) SAS System for Mixed Models. SAS Institute, Cary, NC.

[41] SAS Institute (2002) The SAS Systems for Windows. Version 9.4. SAS Institute, Cary, NC. 
[42] Chen, G. and Wiatrak, P. (2010) Soybean Development and Yield are influenced by Planting Date and Environmental Conditions in the Southeastern Coastal Plain, United States. Agronomy Journal, 102, 1731-1737. http://dx.doi.org/10.2134/agronj2010.0219

[43] Santana, V.M., Bradstock, R.A., Ooi, M.K.J., Denham, A.J., Auld, T.D. and Baeza, M.J. (2010) Effects of Soil Temperature Regimes after Fire on Seed Dormancy and Germination in Six Australian Fabaceae Species. Australian Journal of Botany, 58, 539-545. http://citeseerx.ist.psu.edu/viewdoc/download?doi=10.1.1.463.2634\&rep=rep1\&type=pdf http://dx.doi.org/10.1071/BT10144

[44] Cabrera, H.M., Rada, F. and Cavieres, L. (1998) Effects of Temperature on Photosynthesis of Two Morphologically Contrasting Plant Species along an Altitudinal Gradient in the Tropical High Andes. Oecologia, 114, 145-152. http://dx.doi.org/10.1007/s004420050430

[45] Wilson, C., Hui, D., Nwaneri, E., Wang, J., Deng, Q., Duseja, D. and Tegegne, F. (2012) Effects of Planting Dates, Densities, and Varieties on Ecophysiology of Pigeonpea in the Southeastern United States. Agricultural Sciences, 3, 147-152. http://dx.doi.org/10.4236/as.2012.32017

[46] Ashraf, M.Y., Azmi, A.R., Khan, A.H. and Ala, S.A. (1994) Effect of Water Stress on Total Phenol, Peroxidase Activity and Chlorophyll Contents in Wheat. Acta Physiologiae Plantarum, 16, 185-191.

[47] Haldimann, P. (1999) How Do Changes in Temperature during Growth Affect Leaf Pigment Composition and Photosynthesis in Zea mays Genotypes Differing in Sensitivity to Low Temperature? Journal of Experimental Botany, 50, 543-550. http://dx.doi.org/10.1093/jxb/50.333.543

[48] Vickery, P.J., Brink, V.C. and Ormrod, D.P. (1971) Net Photosynthesis and Leaf Area Index Relationships in Swards of Dactylis glomerata under Contrasting Defoliation Regimes. Journal of the British Grassland Society, 26, 85-90. http://dx.doi.org/10.1111/j.1365-2494.1971.tb00640.x

[49] Kalyani, D.L. (2006) Performance of Rainfed Guar Cultivars under Varied Time of Sowing. M.S. Theses, Acharya N G Ranga Agricultural University, Andhra Pradesh.

[50] Taneja, K.D., Bishnoi, O.P., Rao, V.U.M. and Niwas, R. (1995) Effect of Environment on Growth and Yield of Cluster Bean. Crop Research, 9, 159-162.

[51] Choudhary, R.N., Sharma, O.P. and Choudhary, R.S. (2006) Effect of Varieties and Levels of Sulphur on Growth \& Yield of Cluster Bean. Indian Journal of Fertilizers, 2, 45-47.

[52] Ali, Z., Zahid, M.S., Hassan, M.Z. and Bashir, M. (2004) Sowing Dates Effects on Growth, Development and Yield of Guar (Cyamopsis tetragonoloba L.) under Rainfed Conditions of Pothowar Region. Journal of Agricultural Research, 42, 33-40.

[53] Reich, P.B., Walters, M.B., Tjoelker, M.G., Vanderklein, D. and Buschena, C. (1998) Photosynthesis and Respiration Rates Depend on Leaf and Root Morphology and Nitrogen Concentration in Nine Boreal Tree Species Differing in Relative Growth Rate. Functional Biology, 12, 395-405. http://dx.doi.org/10.1046/j.1365-2435.1998.00209.x

[54] Rogers, C.E. (1973) Influence of Planting Date on Guar Production in Rolling Plain of Texas. The Texas Agricultural Experiment Station. Progress Report, PR-3168.

[55] Yadav, B.D., Joon, R.K., Virender, K., Kumar, V. and Henry, A. (2003) Response of Early Maturing Guar Variety to Date of Sowing and Seed Rate. Advances in Arid Legumes Research, 199-202.

[56] Punia, A., Yadav, R., Arora, P. and Chaudhury, A. (2009) Molecular and Morphological Characterization of Superior Cluster Bean (Cyamopsis tetragonoloba) Varieties. Journal of Crop Science and Biotechnology, 12, 143-148. http://dx.doi.org/10.1007/s12892-009-0106-8

[57] Bhadoria, R.B.S. and Chauhan, V.S. (1994) Response of Clusterbean (Cyamopsis tetragonoloba L.) to Dates of Sowing and Spacing. Indian Journal of Agronomy, 39, 156-157.

[58] Taneja, K.D., Saini, M.L. and Sharma, B.D. (1984) Effect of Dates of Sowing and Row Spacing on the Seed Yield of Guar. Forage Research, 10, 115-117.

[59] Tiwana, U.S. and Tiwana, M.S. (1992) Effect of Sowing Time, Seed Rate and Row Spacing on the Seed Yield of Guar (Cyamopsis tetragonoloba L.) under Rainfed Conditions. Forage Research, 18, 151-153.

[60] Patil, D.V. (2014) Genetic Variability and Sowing Dates Effect of Cluster Bean (Cyamopsis tetragonoloba L. Taub) Genotypes in Semi-Arid Region of Maharashtra, India. Plant Archives, 14, 1-6. 